\title{
PENGARUH PEMBERIAN MOL TERHADAP PERTUMBUHAN DAN PRODUKSI TANAMAN KANGKUNG DARAT (Ipomea reptans Poir)
}

\author{
THE EFFECT OF GIVING MOL TOWARD GROWTH AND PRODUCTION OF KALE \\ (IPOMEA REPTANS POIR) \\ Jumriani. $\mathbf{K}^{11}$, Patang $^{2)}$, Amirah Mustarin ${ }^{3)}$ \\ ${ }^{1}$ Alumni Program Studi Pendidikan Teknologi Pertanian \\ 2 dan ${ }^{3}$ Dosen PTP FT UNM \\ jumriani_k@yahoo.com
}

\begin{abstract}
ABSTRAK
Tujuan penelitian ini adalah untuk mengetahui pengaruh pemberian MOL terhadap peningkatan pertumbuhan, kelangsungan hidup dan produksi kangkung darat. Penelitian ini menggunakan metode Rancangan Acak Lengkap ( $R A L$ ) yang terdiri dari 4 perlakuan dan 3 ulangan yang terdiri dari perlakuan A (24\%), perlakuan B $(30 \%)$, perlakuan C $(36 \%)$ dan kontrol. Parameter yang diamati meliputi pertumbuhan, produksi dan kelangsungan hidup. Teknik analisis data menggunakan analisis varian (ANOVA). Hasil penelitian menunjukkan bahwa perlakuan konsentrasi mol berpengaruh terhadap pertumbuhan dan produksi kangkung. Namun, tidak berpengaruh pada tingkat kelangsungan hidup kangkung. Perlakuan terbaik diperoleh dari penambahan konsentrasi mol $24 \%$ dengan karakteristik tinggi tanaman $46,73 \mathrm{~cm}$, jumlah daun adalah 45 helai pada 28 hari setelah tanam, berat per tanaman adalah $14,67 \mathrm{~g}$, dan berat per polybag adalah $39,91 \mathrm{~g}$ setelah tanam.
\end{abstract}

Kata Kunci : Kangkung, MOL, Pertumbuhan, Produksi, Kelangsungan Hidup

\begin{abstract}
The aims of this research was to determine the effect of giving MOL toward growth, survival and production of kale. This research used a completely randomized design, which consists of 4 treatments and 3 replications consisted of $A$ treatment (24\%), B treatment (30\%), C treatment (36\%) and control. Parameters that was observed include growth, production and survival. Technique of data analyzed using analysis of variance. The results showed that the treatment of MOL concentration had an effect on the growth and production of kale. However, it no effect on the survival rate of kale. The best treatment has resulted from the addition of MOL concentration of $24 \%$ with characteristics plant height was $46.73 \mathrm{~cm}$, the number of leaves was 45 strands on 28 days after planting, weight per plant was $14.67 \mathrm{~g}$, and weight per polybag was $39,91 \mathrm{~g}$ after planting.
\end{abstract}

Keywords: Kale, MOL, Growth, Production, Survival 


\section{PENDAHULUAN}

Indonesia merupakan negara
agraris, yang berarti pertanian
memegang peranan penting dalam
perekonomian nasional. Sektor pertanian
memerlukan perhatian penting
sehingga produksi maupun
produktivitasnya dapat ditingkatkan.
Penduduk Indonesia mengalami
peningkatan pesat dari tahun ke tahun,
namun tidak diimbangi dengan
produksi pangan terutama jenis sayuran.
Oleh karena itu, sektor pertanian
terutama hortikultura khususnya
sayuran mempunyai peluang yang
besar untuk memenuhi salah satu
kebutuhan pangan khususnya sebagai
sumber vitamin.

Peningkatan produktivitas

tanaman sayuran dapat dilakukan dengan beberapa cara, salah satunya adalah pemberian pupuk dengan jenis, dosis dan cara yang tepat. Pupuk organik merupakan pupuk yang berasal dari bahan organik sisa-sisa tumbuhan, hewan, dan kompos. Pupuk organik selain sebagai sumber hara dan sumber energi bagi aktivitas mikroba dalam tanah juga memiliki kelebihan, yaitu dapat memperbaiki kesuburan fisik, kimia dan biologi tanah (Hartatik, 2006). Pupuk organik yang dapat diaplikasikan pada budidaya kangkung darat adalah pupuk organik cair. Pupuk organik cair adalah pupuk yang kandungan bahan kimianya memberikan hara yang sesuai dengan kebutuhan tanaman pada tanah, pupuk organik cair menyebabkan tanaman mudah mengatur penyerapan komposisi pupuk yang dibutuhkan.

MOL adalah larutan hasil fermentasi yang berbahan dasar dari berbagai sumber daya lokal. Larutan MOL mengandung unsur hara mikro dan makro serta mengandung bakteri yang berpotensi sebagai perombak bahan organik, perangsang pertumbuhan, dan sebagai agen pengendali hama dan penyakit tanaman, sehingga $\mathrm{MOL}$ dapat digunakan baik sebagai dekomposer, pupuk hayati maupun pestisida organik terutama sebagai fungisida (Purwasasmita, 2009). Keunggulan penggunaan $\mathrm{MOL}$ adalah dapat diperoleh dengan biaya murah.

Salah satu bahan yang dapat dijadikan MOL adalah bonggol pisang basah dan kering. Kandungan unsur hara fosfor bonggol pisang basah 60,00 $\mathrm{mg}$, bonggol pisang kering $150,00 \mathrm{mg}$, vitamin B1 0,01 mg, karbohidrat 11,60 g, rasio C/N 2,2 (Maudi, 2008). Suparyono (2011) menjelaskan bahwa mikroorganisme lokal bonggol pisang sumber nitrogen dan fosfor bagi tanaman.

Umumnya saat memasak beras, air cuciannya sering sekali dibuang begitu saja oleh masyarakat, Sedangkan, seperti yang telah diketahui bahwasanya pada air cucian beras tersebut masih ada terkandung karbohidrat yang tersuspensi ketika pencucian. Air cucian beras atau leri dapat digunakan sebagai nutrisi tambahan karena mengandung berbagai unsur hara yang diperlukan oleh tanaman serta menghasilkan pertumbuhan akar yang lebih baik.

Limbah air beras putih mengandung nitrogen $0,015 \%$, fospor $16,306 \%$, kalium $0,02 \%$, kalsium 2,944 \%, magnesium $14,252 \%$, sulfur $0,027 \%$, besi $0,0427 \%$, vitamin B1 $0,043 \%$ (Utami, 2003). Hasil fermentasi dari campuran bahan air cucian beras, air kelapa muda, bonggol pisang, dan gula merah yang akan menghasilkan MOL yang diduga dapat memberikan kontribusi yang positif dimana bahasan 
terkait pertumbuhan dan produksi kangkung darat.

\section{TUJUAN PENELITIAN}

Penelitian ini bertujuan untuk mengetahui pengaruh pemberian $\mathrm{MOL}$ terhadap peningkatan pertumbuhan, kelangsungan hidup dan produksi kangkung darat.

\section{METODE PENELITIAN}

$\begin{array}{llr}\text { Jenis } & \text { penelitian ini } & \text { adalah } \\ \text { penelitian } & \text { eksperimen } & \text { yang }\end{array}$ menggunakan rancangan acak lengkap (RAL), dengan menggunakan tabel angka random. Terdapat 4 perlakuan dengan 3 kali ulangan, yaitu perlakuan $A$ pemberian MOL sebanyak $24 \%$, perlakuan $B$ pemberian $\mathrm{MOL}$ sebanyak $30 \%$, perlakuan $\mathrm{C}$ pemberian $\mathrm{MOL}$ sebanyak $36 \%$ dan kontrol (0\%). Jumlah unit percobaan sebanyak 12 unit tanaman dengan ketentuan tata letak setiap perlakuan dilakukan dengan metode undian

Alat yang digunakan dalam penelitian ini meliputi cangkul, Penggaris $60 \mathrm{~cm}$, timbangan digital, pisau, ember, selang berdiameter $0,5 \mathrm{~cm}$, cerek ukur, botol plastik, pulpen, polybag berdiameter $15 \mathrm{~cm}$ dan tinggi $20 \mathrm{~cm}$, Plastik

Bahan yang digunakan dalam penelitian ini adalah bonggol pisang yang diambil dari kabupaten Bantaeng dengan kondisi kering, air cucian beras bilasan pertama, air kelapa muda, gula merah, tanah, benih kangkung darat jenis bangkok LP-1, pupuk kompos kotoran ayam broiler.
Penelitian dilaksanakan di lahan praktek Pendidikan Teknologi Pertanian. Waktu pelaksanaan penelitian dimulai 11 April sampai 25 Mei 2016.

\section{HASIL DAN PEMBAHASAN}

Pertumbuhan tanaman

kangkung darat pada penelitian ini diukur melalui 3 parameter yaitu tinggi tanaman (cm), jumlah daun (helai) dan produksi. Proses pengukuran yang dilakukan yaitu pengukuran tinggi dan jumlah tanaman dilakukan secara manual dengan menggunakan alat tulis dan mistar pada rentang waktu 7, 14, 21 dan 28 Hari Setelah Tanam (HST).

\section{Tinggi Tanaman}

Berdasarkan pengukuran yang diambil langsung dari tempat penelitian, menunjukkan bahwa tinggi tanaman kankung darat pada hari ke-7 (sebelum pemberian perlakuan konsentrasi MOL), yaitu berada berada pada kisaran8,70$9,63 \mathrm{~cm}$ (Gambar 4.1). Setelah pemberian konsentrasi MOL, hari ke-14, tinggi tanaman kangkung darat juga belum memiliki perbedaan antar perlakuan. Tinggi tanaman kangkung darat mengalami perbedaan setelah hari ke-21. Perbedaan tinggi tanaman kangkung darat semakin mengalami perbedaan hingga hari ke-28. Tinggi tanaman kangkung darat pada hari ke28, perlakuan pemberian konsentrasi MOL \% (kontrol) memiliki tinggi tanaman yang terendah, yaitu $36 \mathrm{~cm}$, sedangkan tanaman kangkung darat perlakuan pemberian $\mathrm{MOL} 24 \%$ memiliki tinggi tanaman tertinggi jika dibandingkan perlakuan lain, yaitu $46,73 \mathrm{~cm}$. 


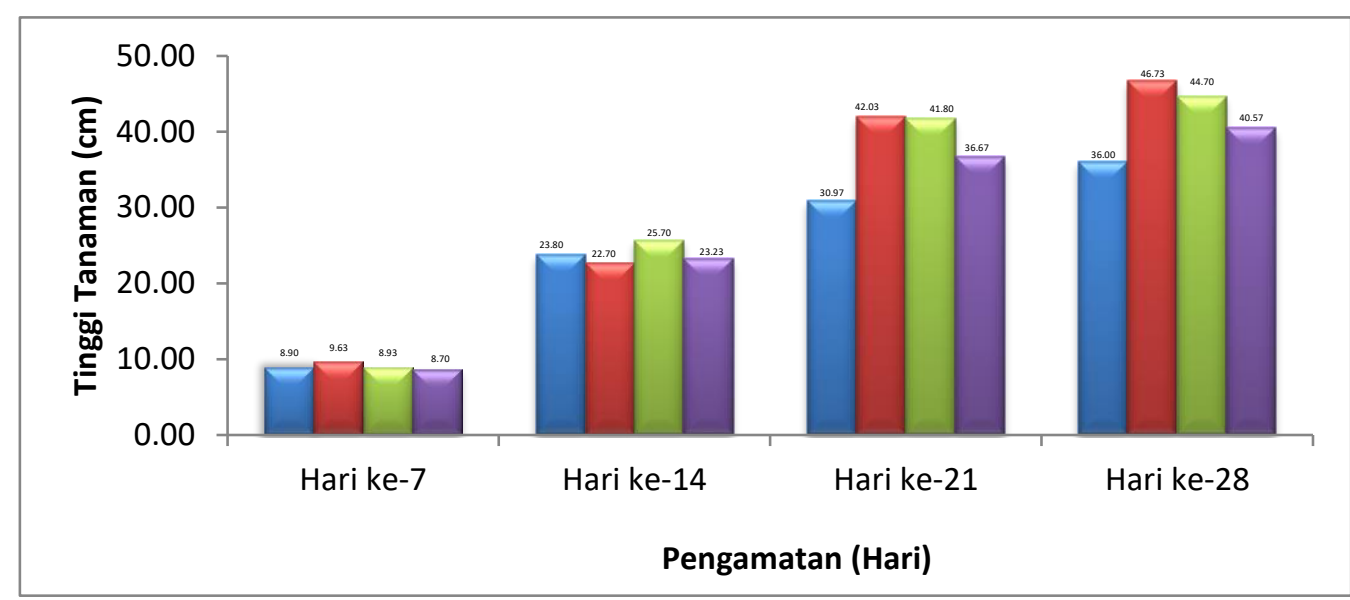

Gambar 1.

Pengaruh Konsentrasi MOL Terhadap Tinggi Tanaman Kangkung Darat (Ipomea reptans Poir)

Keterangan:
$\square$ - Perlakuan Kontrol
$\square$ : Perlakuan A $(24 \% \mathrm{Mol})$
$\square$ : Perlakuan B (30\% Mol)
$\square$ : Perlakuan C (36\% Mol)

Tinggi tanaman kangkung darat pada hari ke- 21 setelah tanam terletak pada perlakuan pemberian MOL yaitu berkisar 36,67-42,03 cm, sedangkan tinggi tanaman perlakuan kontrol hanya $30,97 \mathrm{~cm}$. Hal ini disebabkan pemberian MOL mampu meningkatkan jumlah mikroorganisme yang terdapat dalam tanah. Jumlah mikroorganisme perlakuan pemberian MOL berkisar 10,610,8 log cfu/ml, atau dengan kata lain terdapat 10 milyar jumlah mikroorganisme pada tanah. Jumlah mikroorganisme yang tinggi mempunyai kesuburan tanah yang berkorelasi positif dengan tinggi tanaman kangung darat. Menurut hasil penelitian Mulyono (2012) menyatakan bahwa tanah subur terdapat 10-100 juta mikroorganisme. Menurut Maspary (2012) menyatakan bahwa MOL bonggol pisang mengandung 7 mikroorganisme yang sangat berguna bagi tanaman yaitu: Azospirillium, Azotobacter, Bacillus, Aeromonas, Aspergillus, mikroba pelarut phospat dan mikroba selulotik serta adanya zat pengatur tumbuh giberlin dan sitokinin yang ada dalam kandungan MOL yang merangsang pertumbuhan tanaman dan mengatur pertumbuhan tanaman.

Tinggi tanaman kangkung darat pada umur 28 hari setelah tanam menunjukkan perlakuan MOL $24 \%$ dan $36 \%$ tertinggi, yaitu $46,73 \mathrm{~cm}$ dan 44,7 $\mathrm{cm}$ disebabkan karena mengandung unsur hara $\mathrm{N}, \mathrm{P}$, dan $\mathrm{P}_{2} \mathrm{O}_{5}$ yang dibutuhkan tanaman untuk sintesa asamasam amino dan protein, terutama pada titik tumbuh tanaman sehingga mempercepat proses pertumbuhan tanaman seperti pembelahan sel dan perpanjangan sel sehingga meningkatkan tinggi tanaman (Gardner dalam Dhani $d k k$, 2014). Salah satu faktor budidaya kangkung darat yang 
perlu diperhatikan adalah pemberian unsur hara atau pemupukan untuk menyuburkan tanaman. Unsur hara yang diperlukan tanaman kangkung darat menurut Margianto dalam Malik (2009) adalah nitrogen $(\mathrm{N}) 69 \mathrm{~kg} / \mathrm{ha}$, fosfor $\left(\mathrm{P}_{2} \mathrm{O}_{5}\right) 54 \mathrm{~kg} / \mathrm{ha}$, dan kalium $\left(\mathrm{K}_{2} \mathrm{O}\right) 21$ $\mathrm{kg} / \mathrm{ha}$.

Kebutuhan $\mathrm{pH}$ tanah antara 5,66,5 yaitu tanah gembur dan banyak mengandung bahan organik (Inggah, 2012). Fosfor berperan dalam pertumbuhan dan merupakan penyusun sel hidup. Fosfor sangat berperan aktif dalam mentransfer energi di dalam sel, mengubah karbohidrat, dan meningkatkan efisiensi kerja kroroplas (Hakim dalam Dhani, 2014). Selain itu, menurut Foth dalam Dhani dkk (2014) menyatakan bahwa penetapan dosis dalam pemupukan sangat penting dilakukan karena akan berpengaruh tidak baik pada pertumbuhan jika tidak sesuai dengan kebutuhan tanaman. Oleh karena itu, pemberian MOL 24\%, merupakan dosis yang baik dalam mencukupi kebutuhan hara tanaman pada tanaman kangkung darat dan memberikan peningkatan terhadap nilai $\mathrm{pH}$ tanah perlakuan $24 \%$ yaitu 5,75 dengan tekstur tanah yang berpasir dan tidak liat, berbeda dengan tekstur tanah perlakuan kontrol yang memenuhi tekstur tanah yang liat.

\section{Jumlah Daun}

Identifikasi lapangan yang di dapatkan dengan menggunakan perhitungan dan pencatatan terhadap rata-rata, maka bisa di katakan jumlah daun pada hari ke-7 memiliki jumlah daun yang serupa yaitu 10-13 helai daun. Sedangkan pada hari ke-28 hari setelah tanam jumlah daun mengalami peningkatan yaitu pada perlakuan $36 \%$ perlakuan MOL jumlah daun 47,67 helai daun dapat dilihat pada Gambar 4.2.

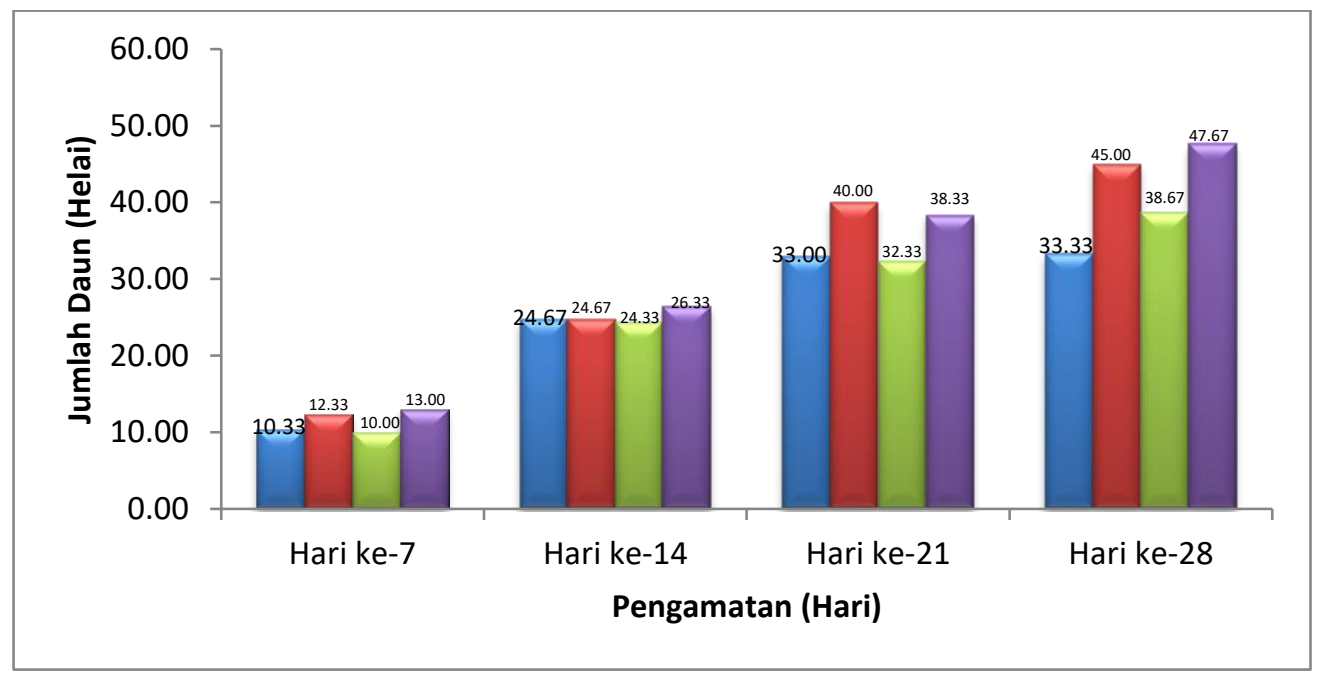

Gambar 2.

Pengaruh Konsentrasi MOL Terhadap Jumlah Daun Kangkung Darat (Ipomea reptans

Keterangan:

Poir)
$\square=$ Perlakuan Kontrol
$\square$ = Perlakuan A $(24 \%$ Mol $)$
$\square=$ Perlakuan B (30\% Mol)
$\square$ = Perlakuan C (36\% Mol) 
Setelah melakukan pengamatan pada tanaman kangkung darat pada MOL (24\%) umur 21 hari setelah tanam memperlihatkan perlakuan $\mathrm{MOL} 24 \%$ dan $36 \%$ memiliki jumlah daun tertinggi dibandingkan perlakuan $\mathrm{MOL} 30 \%$ dan kontrol. Setelah umur 28 hari setelah tanam, jumlah daun tanaman kangkung memperlihatkan pebedaan yang signifikan antara jumlah daun perlakuan penambahan MOL $30 \%$ dan perlakuan kontrol. Konsentrasi MOL yang diberikan sangat berpengaruh terhadap jumlah daun tanaman kangkung. Penambahan MOL menyebabkan jumlah mikroorganisme mengikat dan berkorelasi positif dengan peningkatan jumlah daun.

Jumlah daun tanaman kangkung darat pada perlakuan MOL (36\%) pada umur 28 hari setelah tanam disebabkan karena mikroorganisme dalam tanah sudah terurai dan sudah memenuhi kebutuhan tanaman. Menurut Hasiholan (2000), keberadaan mikroorganisme yang terkandung dalam MOL juga mempengaruhi peningkatan lebar daun tanaman selada seperti Azospirillium sp yang berfungsi untuk memperbaiki perakaraan sehingga mempengaruhi penyerapan unsur hara. (Diana $d k k$, 2012).

Kualitas tanah yang digunakan dalam penelitian ini adalah lempung berpasir dan lempung. Menurut Hanafiah (2005) tanah lempung berpasir mempunyai rasa kasar dan agak terasa jelas dan juga akan membentuk bola yang agak keras tetapi akan mudah hancur, tanah lempung tidak terasa kasar dan juga tidak terasa licin dapat membentuk bola yang agak teguh dan dapat sedikit digulung dengan permukaan yang mengkilat selain itu tanah lempung juga dapat melekat dan masih bagus untuk budidaya tanaman kangkung darat.

\section{Bobot Per Tanaman Hari ke-30 Setelah Tanam}

Pada (Gambar 4.3) dapat kita lihat hasil pengukuran terhadap rata-rata bobot per tanaman kangkung darat. menunjukkan bobot tanaman kangkung darat perlakuan pemberian konsentrasi MOL lebih tinggi dibandingkan dengan perlakuan $0 \%$ (kontrol).

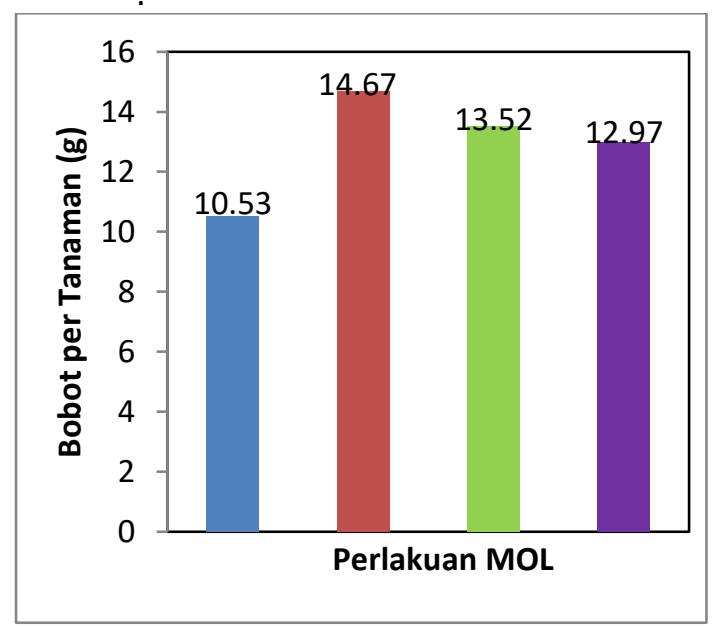

Gambar 3.

Pengaruh Konsentrasi MOL Terhadap Bobot Basah Per Tanaman Kangkung Darat (Ipomea reptans Poir)

$$
\begin{aligned}
& \text { Keterangan: } \\
\square= & \text { Perlakuan Kontrol } \\
\square= & \text { Perlakuan A }(24 \% \mathrm{Mol}) \\
\square= & \text { Perlakuan B }(30 \% \mathrm{Mol}) \\
\square= & \text { Perlakuan C }(36 \% \mathrm{Mol})
\end{aligned}
$$

Hasil perhitungan bobot per tanaman kangkung darat menunjukkan perlakuan pemberian konsentrasi MOL memiliki bobot yang lebih tinggi dibandingkan perlakuan kontrol. MOL menyebabkan jumlah mikroorganisme yang terdapat dalam tanah meningkat. 
Peningkatan jumlah mikroorganisme menyebabkan terjadinya peningkatan kesuburan tanah dan ketersediaan unsur hara yang tinggi disebabkan oleh hasil metabolisme mikroorganisme. Proses metabolisme oleh mikroorganisme mengubah senyawa kompleks menjadi senyawa sederhana atau mensintesis senyawa-senyawa yang dibutuhkan oleh pertumbuhan tanaman. Senyawasenyawa yang dihasilkan sangat berperan dalam proses fisiologi dan metabolisme tanaman kangkung darat. Menurut Dhani $d k k$ (2014) jumlah perlakuan $\mathrm{A}(24 \%)$ dan perlakuan $\mathrm{C}(36 \%)$ diduga disebakan karena jumlah mikroorganisme berada pada titik optimal. Perlakaun $24 \%$ pemberian MOL telah cukup menyediakan unsur hara yang dibutuhkan tanaman kangkung darat untuk proses fisiologi dan metabolisme, dengan demikian proses fisiologi dan metabolisme dalam tanaman akan memacu pertumbuhan tanaman, yang mengakibatkan peningkatan berat segar konsumsi. Konsentrasi MOL terbaik adalah konsentrasi 24\%, karena pada konsentrasi tersebut jumlah unsur hara cukup memenuhi kebutuhan tanaman. Hal ini didukung oleh penelitian Sari dan Surti (2012), bahwa konsentrasi MOL bonggol pisang terbaik terhadap pertumbuhan adalah $24 \%$.

\section{Bobot per polybag}

Hasil pengukuran terhadap ratarata bobot tanaman per polybag menunjukkan bahwa perlakuan pemberian MOL $36 \%$ memiliki bobot tertinggi sedangkan perlakuan kontrol memiliki bobot yang terendah (Gambar 4).

Pengukuran bobot tanaman per polybag pada hari ke-30 menunjukkan bobot tertinggi terletak pada perlakuan $C$ $(36 \%)$ yaitu $41,51 \mathrm{~g}$, menyusul perlakuan penambahan MOL (24\%) 39,91 g, perlakuan MOL (30\%) sebesar 36,52 g, dan terendah pada perlakuan Kontrol yaitu $31,52 \mathrm{~g}$.

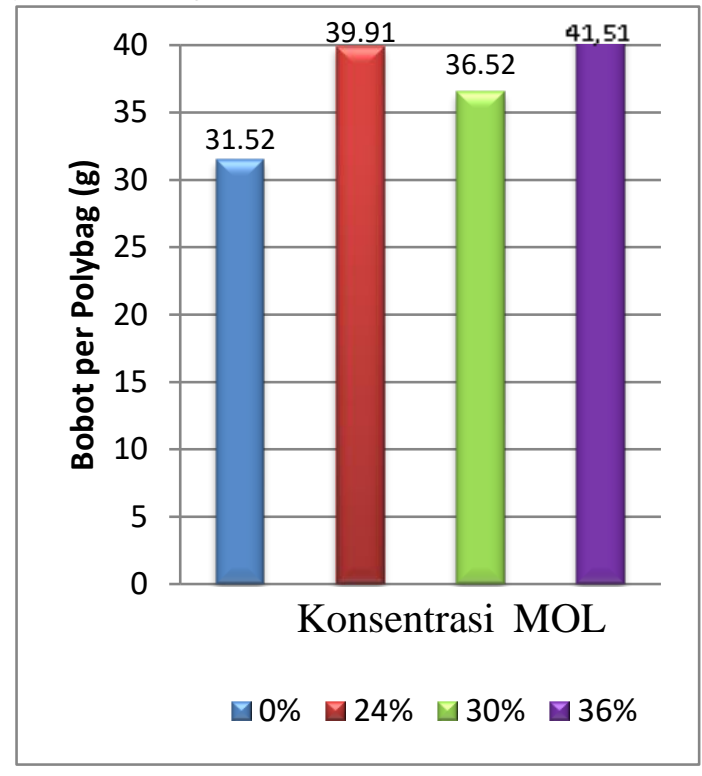

\section{Gambar 4.}

Pengaruh Konsentrasi MOL Terhadap Bobot Basah Per Polybag Kangkung Darat (Ipomea reptans Poir)

Keterangan:

$$
\begin{aligned}
\square & =\text { Perlakuan Kontrol } \\
\square & =\text { Perlakuan A (24\% Mol) } \\
\square & =\text { Perlakuan B (30\% Mol) } \\
\square & =\text { Perlakuan C (36\% Mol) }
\end{aligned}
$$

Hasil penimbangan bobot per polybag menunjukkan bobot tanaman perlakuan pemberian konsentrasi $\mathrm{MOL}$ lebih tinggi dibandingkan perlakuan kontrol. Namun, bobot tanaman kangkung darat tertinggi (bobot per polybag) dihasilkan oleh perlakuan MOL $24 \%$ dan 36\%. Menurut Buckman (1969) bahwa suatu tanaman akan tumbuh dan mencapai tingkat produksi tinggi bila unsur hara yang dibutuhkan tanaman berada dalam keadaan cukup tersedia dan berimbang di dalam tanah 
dan unsur $\mathrm{N}, \mathrm{P}, \mathrm{K}$ merupakan unsur hara makro yang mutlak diperlukan tanaman. Bila salah satu unsur tersebut kurang atau tidak tersedia dalam tanah, akan mempengaruhi pertumbuhan dan produksi tanaman. Perlakuan pemberian konsentrasi MOL menyebabkan tanaman kangkung darat memperoleh unsur hara yang lebih baik, melalui hasil metabolisme dan sintesis oleh mikroorganisme.

\section{Kelangsungan Hidup}

Kelangsungan hidup tanaman kangkung darat yang di dapatkan dari hasil perhitungan. menunjukkan pada perlakuan MOL $24 \%, 36 \%$, perlakuan $\mathrm{K}$ (kontrol) masing-masing sebesar 100\% jumlah tanaman yang hidup. Perlakuan MOL memilikinilai terendah yaitu sebesar $88,87 \%$ tanaman yang hidup. Seperti yang terlihat pada (Gambar 4.5)

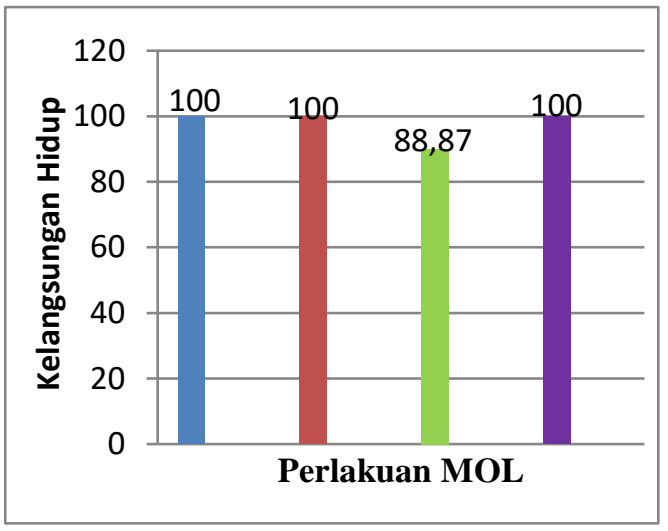

Gambar 5.

Pengaruh Konsentrasi Mol Terhadap Kelangsungan Hidup Kangkung Darat (Ipomea reptans Poir)

Keterangan:

$\square=$ Perlakuan Kontrol

$\square=$ Perlakuan A (24\% Mol)

$\square=$ Perlakuan B (30\% Mol)

$\square=$ Perlakuan C (36\% Mol)
Banyaknya jumlah tanaman yang hidup disebabkan oleh unsur hara dalam tanah mencukupi untuk pertumbuhan tanaman kangkung darat serta jumlah mikroorganisme mencapai kebutuhan tanah. Rendahnya jumlah tanaman yang hidup disebabkan karena laju pertumbuhan tanaman mempengaruhi jumlah fotosintat yang dihasilkan dan tidak maksimalnya proses perkecambahan biasanya dikarenakan kurangnya penyerapan air, suhu, cahaya, oksigen dan medium sehingga proses perkecambahan tidak maksimal dan akan berdampak pada tidak terjadinya pembentukan akar. Telihat perbedaan antara penelitian yang dilakukan oleh Azzamy (2016) dengan penelitian yang didapatkan di lapangan dengan hasil bahwa tanaman membutuhkan nutrisi yang cukup yaitu kandungan unsur hara makro dan unsur hara mikro agar dapat tumbuh dan berkembang dengan baik.

\section{Jumlah Mikrorganisme Hari ke-2, ke-3 dan ke-4}

Hasil menunjukkan jumlah mikroorganisme pada MOL mengalami peningkatan selama proses fermentasi. Jumlah mikroorganisme tertinggi dihasilkan pda fermentasi MOL hari ke-3 yaitu 11,6 log cfu/ml. Setelah fermentasi hari ke-3, jumlah mikroorganisme telah mengalami penurunan, jumlah mikroorganisme mengalami penurunan sebanyak 1,1 log cfu/ml, yaitu 10,7 log cfu/ml.

Mikroorganisme lokal (MOL) yang dimanfaatkan selama proses penelitian adalah MOL yang telah difermentasi selama 5 hari. Penelitian ini berdasarkan pada jumlah mikroorganisme yang masih mencapai 10,0 log cfu/ml. Jumlah mikroorganisme 
10,0 log cfu/ml masih memenuhi standar mikroorganisme tanah yang subur, yaitu $8,0 \log \mathrm{cfu} / \mathrm{ml}$.

Jumlah mikroorganisme pada MOL yang telah diaplikasikan pada tanah sesuai perlakuan, yaitu, pemberian konsentrasi MOL 24\%, 30\%, dan 36\% menunjukkan hasil yang serupa. Jumlah mikroorganisme berkisar antara 10,610,8 log cfu/ml. Hasil ini menunjukkan jumlah MOL yang diberikan tidak berpengaruh terhadap jumlah mikroorganisme awal pada tanah.

Hasil perhitungan terhadap jumlah mikroorganisme dapat dilihat pada Gambar 6. berikut.

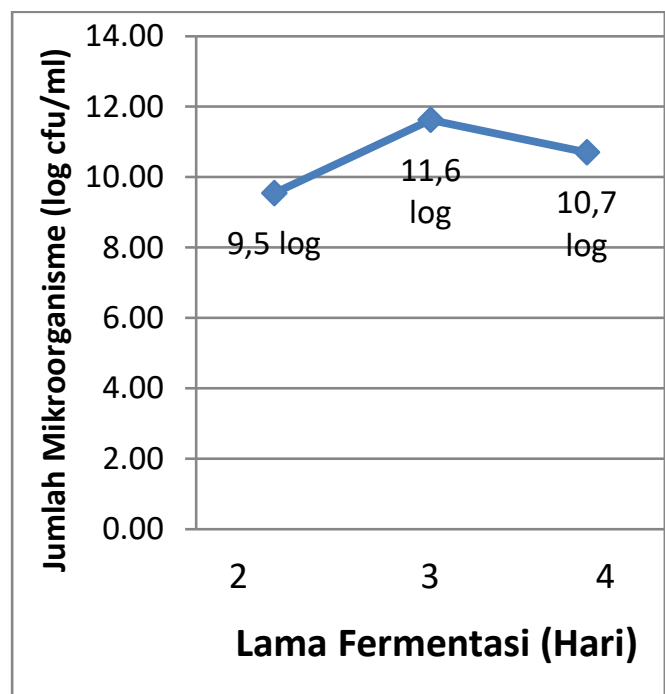

Gambar 6.

Jumlah Mikroorganisme (Sumber:

Laboratorium Pertanian Universitas

Hasanuddin)

Keterangan:

Fermentasi Hari ke-2 $=9,5$ log

Fermentasi Hari ke-3 $=11,6$ log

Fermentasi Hari ke-4=10,7 log

Jumlah bakteri pada hari ke-2 sebanyak 9,5 log cfu/ml dan meningkat pada hari ke-3 sebesar 11,6 log cfu/ml, tetapi pada hari ke-4 jumlah bakteri turun menjadi 10,7 log cfu/ml. Selanjutnya, jumlah bakteri pada hari ke-5 pada saat aplikasi MOL, jumlah bakteri dapat dilihat pada Gambar 7.

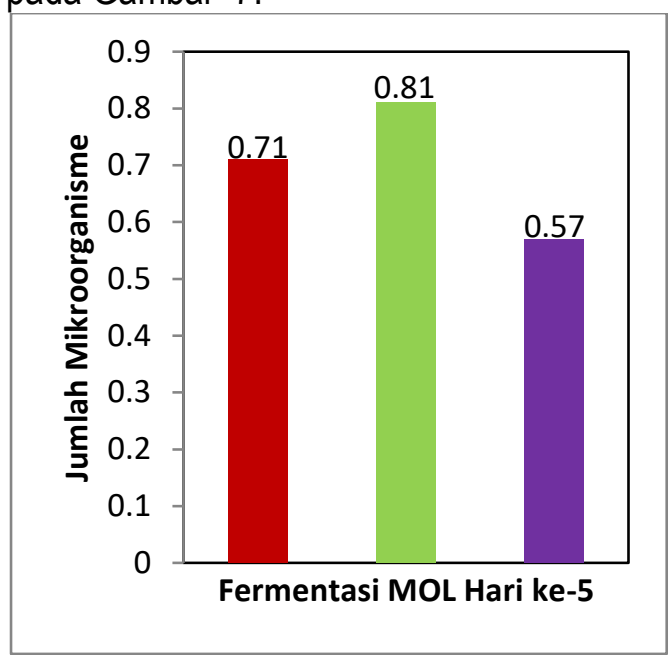

Gambar 7.

Jumlah Mikroorganisme Lokal (MOL) yang Diaplikasikan ke Tanaman Kangkung Darat

Keterangan:

$$
\begin{aligned}
\square & =\text { Perlakuan A }(24 \% \mathrm{Mol}) \\
\square & =\text { Perlakuan B (30\% Mol) } \\
\square & =\text { Perlakuan C (36\% Mol) }
\end{aligned}
$$

MOL dilakukan dengan metode mikroaerofilik dengan menggunakan selang berdiameter $0,5 \mathrm{~cm}$ yang ditancapkan pada wadah fermentasi MOL agar mikroorganisme tetap mendapatkan oksigen. MOL dengan bahan dasar bongggol pisang, air kelapa, air cucian beras dan gula merah. Dalam proses fermentasi adalah karbohidrat akan diubah menjadi gula oleh $S$. cerevisiae, gula diubah menjadi alkohol dan alkohol akan diubah oleh $A$. aceti menjadi asam asetat (Widiastuti, 2008).

Hasil penelitian Jumlah bakteri pada hari ke-2 sebanyak 9,5 log cfu/ml dan meningkat pada hari ke-3 sebesar 
$11,6 \log \mathrm{cfu} / \mathrm{ml}$ hal ini sesuai dengan penelitian (Mulyono, 2012) bahwa tanah subur terdapat 10-100 juta mikroorganisme dalam setiap g tanah, tetapi pada hari ke-4 jumlah bakteri turun menjadi 10,7 log cfu/ml. Selanjutnya, jumlah bakteri pada hari ke-5 pada saat aplikasi MOL jumlah mikroorganisme terbanyak pada perlakuan $B$ sebesar 10,8 log cfu/ml, menyusul perlakuan A sebesar $10,7 \mathrm{log}$ cfu/ml dan perlakuan $\mathrm{C}$ sebesar 10,6 log cfu/ml. Hasil penelitian sama dengan penelitian yang dilakukan oleh (Maspary, 2012) bahwa MOL yang telah difermentasi 4-5 hari sudah bisa diaplikasikan pada tanaman karena sudah mencapai jumlah mikroorganisme yang dibutuhkan tanah.

\section{KESIMPULAN}

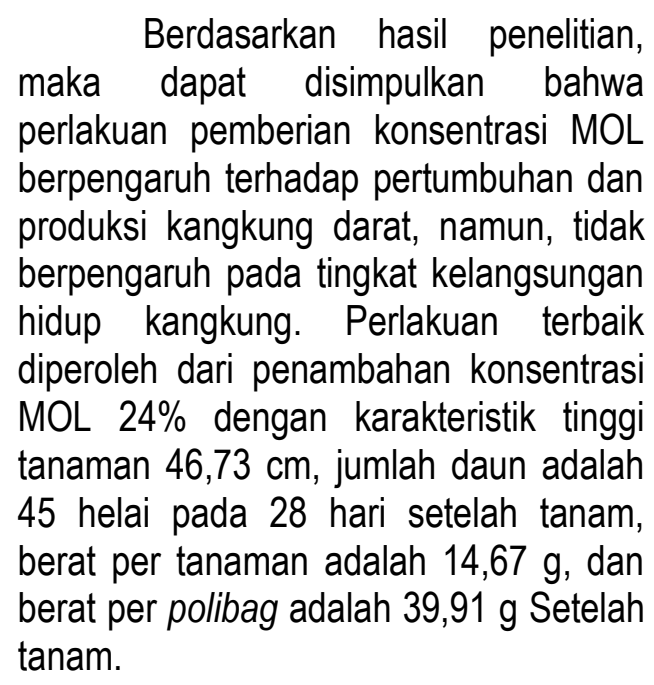

\section{DAFTAR PUSTAKA}

Azzamy, 2016. Pengaruh pH nutrisi pada tanaman hidroponik.

Diana Novita Sari, Surti Kurniasih, R. Teti Rostikawati. 2012. Pengaruh Pemberian Mikroorganisme Lokal (Mol) Bonggol Pisang Nangka terhadap Produksi Rosella

(Hibiscus Sabdariffa L). Bogor

Dhani,H., Wardato., Rosmim,.2014. Pengaruh Pupuk Vermikompos

Pada Tanah Inceptisol Terhadap Pertumbuhan Dan Hasil Sawi Hijau (Brassica Juncea L). Fakultas Pertanian Riau. Riau

Hartatik. 2006. Pupuk Kandang, Pupuk Organik, dan Pupuk Hayati, Kangkung Darat, Bogor: Balai Besar Penelitian dan Pengembangan Sumber Daya Lahan Pertanian.

Hasiholan, Bistok. Suprihati dan Muryas R. Isjwara. 2000. Pengaruh Perbandingan Nitrat dan Amonium terhadap pertumbuhan dan Hasil Tanaman Selada (Lactuca sativa L) yang dibudidayakan Secara Hidroponik. Makalah Seminar. Salatiga : UKSW

Hanifah, Ali kemas. 2005. Dasar-dasar IImu Tanah. Raja Grafindo persada: Jakarta

Maspary.2012. Apa Kehebatan MOL Bonggol Pisang, Jakarta: Gramedia.

Maudi, Wulandari dan Suhastyo. 2008. Kandungan Gizi dalam Bonggol Pisang. Jakarta: Agromedia.

Mulyono. 2012. Membuat Mol dan Kompos dari Sampah Rumah Tangga. Jakarta: Agromedia pustaka.

Malik, 2009. Unsur Hara dalam Tanah. Universitas jember. 
Purwasasmita, M. 2009. Mikroorganisme

Lokal Sebagai Pemicu Siklus

Kehidupan dalam Bioreaktor

Tanaman. Seminar Nasional

Teknik Kimia Indonesia. $19-20$

Oktober 2009.

Sari dan Surti. 2012. Unsur Hara

Tanaman dengan Konsentrasi

MOL. Bogor

Suparyono, 2011. Pengaruh

Pemberian Mikroorganisme

Lokal (Mol) Bonggol Pisang

Nangka Terhadap Produksi

Rosella (Hibiscus sabdariffa

l)

Utami S.N.H. 2003. Nutrisi Tanaman.

Yogyakarta: Jurusan Tanah

Fakultas Pertanian

Universitas Gadjah Mada.

Widiastuti.2008. Balai Penelitian

Bioteknologi Pekebunan

Indonesia: Keefektifan

Beberapa Decompocer Untuk

Pengomposan Limbah Sludge

Pabrik Ketas Sebagai Bahan-

Bahan Baku Pupuk Organik.

BS Vol 44 No 22 Desember

2009:99-110. 